\title{
THE SULTAN, PARTI RAKYAT BRUNEI, AND INTERNATIONAL INTEREST IN NORTH KALIMANTAN AFFAIR 1962-1963
}

\author{
Nour Muhammad Adriani \\ Departemen Pendidikan Sejarah, FPIPS, UPI \\ adrian.2bdg@gmail.com
}

\begin{abstract}
The Brunei Revolution in 1962 despite of its small scale is an important event which lead to an international conflict occurred in the region in years next. As its international historical context, the issue about who is the most responsible to trigger it remain in debate. The Sultan of Brunei, Parti Rakyat Brunei and international powers were the player of its importance in the Cold War context. Through historical method uses primary sources of newspapers and published documents as well as recent findings, this paper will assess the question: who is the most likely party who triggered the event as well as contribute to its failure? From the perspective of historical chronology, the Sultan is likely the most responsible for the turmoil. His reluctance and unresponsive attitude; decision to seize the people's democracy; and arrogance in Malaysia's case, left all interested parties gaining momentum to pressure him to decide. The Brunei People Party (PRB) became one of the parties who tried to do it, with its often-neglected aspirations for national independence, supported by the people, sympathetic neighbors, and left-leaning nations at the time. This failed rebellion also resembles a symbol of relatively untouchable people of monarch which absent from historical critics regarding its powerful position in the modern politics.
\end{abstract}

Keywords: $\quad$ Brunei Revolution, Sultan of Brunei, Parti Rakyat Brunei, historical method

\section{INTRODUCTION}

Southeast Asia in the early 1960s was in a drastic transition from a source of European industrial raw materials to one of the centers of the political movement during the Cold War around the world (Wallerstein in Yangwen et.all, 2010). Several independent countries began to raise their voice actively, their aspirations and ideas who challenging European power present as colonialist in the region. At that time, military bases in Singapore and the colonial administration in Brunei and North Borneo, still leaves suspicions about British good intentions to end its imperialist desires (Deery, 2007).

Soon after defeated Japanese and returned to its colonial possessions in Southeast Asia, British planned to decolonize Malaya, Singapore, and North Borneo. The early proposal was to merge all the territory into two political unit: Malayan Union in the west and North Borneo Federation in the east (Bakar, 2014). Although not directly invited to dialogue, neighboring countries such as Indonesia and the Philippines declared no objection to the proposal and considered it as a good option to end colonialism in the region.

The outbreak of a short-lived rebellion of PRB at the end of 1962, drastically changed the situation. Indonesia questioned the "aspirations" of the people of North Borneo over the creation of Malaysia and accused British of manipulated it (Bintang Timur, 15 December 1962). The Philippines reviving the historical demands of Sabah as part of the Sulu Sultanate (Poulgrain, 2014: Duta Masyarakat, 28 December 1962). The Sultan of Brunei decided to remain under British protection rather than joining Malaysia (Manan, 2015). Meanwhile, the Malayan government responded emotionally by issuing statements alleging that the communists and the Indonesian government were behind the rebellion. All this dynamic led to the escalation of the conflict that culminated in the politics of confrontation in 1963-1966 (Poulgrain, 2014).
Who was most responsible for the revolt itself sparked some speculations. Malaysian historians such as Ramlah Adam, supported by Alexander N. Shaw, argues that Indonesia has been behind the rebellion from the beginning, through its influence on PRB where its main figure, A. M. Azahari has a very close relationship with Indonesian political spectrum, especially the left and communist (Adam, 2004; Shaw, 2016). In some aspect, this is supported by both Kahin and Harclerode's which reveal the role of the Indonesian military assisting the preparation of the Tentara Nasional Kalimantan Utara (TNKU) or North Borneo National Army (the military wing of the PRB) both in training and arms throughout 1962 (Kahin, 2003; Harclerode, 2001). The "radical" similarity between the PRB and the Partai Komunis Indonesia (PKI) or Indonesian Communist Party which controls the foreign ministry under Subandrio, also important to be considered. Thus, the rebellion was planned along with Indonesia's military direct involvement within TNKU.

Meanwhile, the Brunei historians such as Pehin Jamil and Zaini Ahmad, argue that the PRB movement was a localized nationalistic action regarding many acknowledgements of the PRB figures themselves about the non-communist nature - as often alleged - from PRB before and after the rebellion (Ahmad, 1989; Jamil, 2003). Azahari himself refused to be identified as a communist and declared that he was willing to cooperate with every party include the communist to achieve its goals for Brunei independence vision (Ahmad, 1989).

Another fact as Jamil (2003) comment is that there was contact with General Nasution, one of Indonesian Army leader, through a letter which suggested Azahari and PRB to pursue a political change through a constitutional way. This standing perhaps visible when the rebellion took place, the PRB did not attempt to replace the monarchy system, even the Sultan in his position. The act of rebellion was precisely the effort to preserve the Sultan position even expand it who were HISTORIA: Jurnal Pendidik dan Peneliti Sejarah, p-issn:2620-4789 | e-issn:2615-7993 
likely eroded if Brunei joins Malaysia. On the other hand, this action can be interpreted as an attempt to "remind" the Sultan to restore the sovereignty of the people he ignored by hanging parliament from the 1962 democratic election.

Another view reveals the role of the international company, Shell Oil as the responsible party behind this event as disclosed by Abdul Harun Majid (2007) supported by Greg Poulgrain (2014). According to him, the company has an interest in the existing Brunei under British influence due to economic consideration as exploration requires longterm stability. The acquisition of Brunei into Malaysia or the formation of the Federation of North Borneo will result in political turmoil which is very detrimental to the business. Brunei weakness, British military and control, and regional political dynamics were the main reason for the total abolition of "radical" movements such as PRB which become necessary. The involvement of Shell Oil Company, as Poulgrain argues is possible with its close connection with the British Offices of Colonial Affairs, where information between London, Kuala Lumpur, and Brunei was accessible (Majid, 2007).

Although brief, most scholars agree that the Brunei rebellion is an important historical point that started the conflict, even persists in reshaping regional politics until today. George McTurnan Kahin, mentions that before this incident there was no sign of clarity of the opposition even just the interests of Indonesia or the Philippines in the North Borneo issues. The rebellion and the British-Malayan response later made the opposition from its two closest neighbors became stronger. He further mentions how minor shocks in Brunei brought the consequences of international involvement in the presence of British, Commonwealth states, China and even the United Nations (Kahin, 2003). The perspective of this event itself from the beginning impacted to the relations of regional countries in an awkward and unfriendly atmosphere. This view is even exacerbated by the nationalistic historical perspective adopted in each country.

This study will examine who is the most responsible party behind the Brunei rebellion of 1962. A quick review indicates the fourth alternative that missing from attention other than the three general views that have been expressed earlier as the position of the Sultan of Brunei at that time. When we examine more in-depth, all the problems concerning North Borneo are absent from the critical role. The position factor as paramount ruler - to this day - poses a challenge that allows historical bias. Some descriptions will help how this critical perspective leads to the Sultan's inability to manage the situation that led to the outbreak of the PRB's premature rebellion and the wider conflict in the region.

\section{METHOD}

This research uses historical method, consist of heuristic process (sources exploration), critics including its reliability, originality, and credibility of sources used. The data come from primary (published documents, newspapers, and biography) as well as secondary sources (books and contemporary journals). Interpretation is analytical tools in linking the sources towards art of historical writings (Kuntowijoyo, 2005; Herlina, 2011; Langlois \& Seignobos, 2015)

\section{FINDINGS}

\section{British and Southeast Asia Decolonization}

After the Second World War, the British returned to power in the former territories that Japan captured, among others, the Malayan Peninsula, Sarawak, Sabah, Brunei and Singapore. Myanmar has become independent through nationalist struggles such as Aung San and $\mathrm{Ba}$ Maw who have chosen to cooperate with British at the end of war (Tarling, 1993). The proposal on the Malayan Union to merge nine of Malay Sultanates in peninsula along with British strait colonies, which received a widespread rejection from people, triggered a communist uprising in 1948. The British revoked the proposal and replaced it with the federation system until the transfer of independence in 1957 (Andaya \& Andaya, 2017). Meanwhile, the status of North Borneo was still unclear. The British administration ruled directly in Sabah and Sarawak by a governor with the support of local bureaucracy, the natives and immigrant communities. Brunei was under British protection, still following the Treaty of 1888 and Supplementary Agreement 1905, under residency system (Tarling, 1993; Andaya \& Andaya, 2017).

Some decolonization plans have indeed become the subject of conversations among the British colonial officials. The first attempt was made after the proposed formation of the North Borneo Federation, which was initiated in 1953 (Ahmad, 1989; Bakar, 2014; Harry, 2015). The proposal set out from the review that Sabah and Sarawak lack the financial ability to administer their own government, while Brunei was too small regarding territory and population scale to become an independent state. The same issue became a point of rejection by Brunei who feared that its oil royalties would be used to subsidize the federation. At the same time, the sultan gained a high share of oil because of the small size of Brunei (Majid, 2007; Harry, 2015; Duta Masyarakat, 11 December 1962).

A proposal to unify North Borneo before merging it with the administration of the Malay Peninsula was rejected by the Sultan who also feared his economic sovereignty and political supremacy will be disrupted (Majid, 2007; Bakar, 2014). In 1956 a political group supporting the unification of three British territories under the sultanate established the Brunei People's Party (Ahmad, 1989; Andaya \& Andaya, 2017). They encourage democratisation through open elections and carrying aspiration to change the absolute monarchical system to constitutional.

In the 1959 Sultan's initiated constitutional change supported by British transformed Brunei into a constitutional monarchy promising legislative elections in 1961 Ahmad, 1989, Majid, 2007). This development changed the policy of decolonisation with plans to establish a Sabah-Sarawak federation without Brunei as the early stated. Some demographic factors also end up making Brunei's position to join the new Federation highly desirable. The proposed federation was strongly rejected by the PRB which gained popularity from the charismatic leader of A.M. Azahari, its chairman since 1961 (Ahmad, 1989; Bintang Timur, 11 December 1962). 
Despite its "radical" view to some degree "un-compromise" toward imperialism, PRB until the early 1960s still pursued diplomatic ways by engaging in its aspirations both to the Sultan, British administration, and Malayan government (Ahmad, 1989; Majid, 2007; Poulgrain, 2014). These three parties, although in some respects have similarities with PRB, did not seem to welcome their active role, partly because they were sensitive to Azahari's close ties with Indonesia. PRB began to push more after the Sultan decided to postpone the election almost a year. During this period, the Sultan carried out many suspicious political manoeuvres such as insisting on forming an armed force, began to show support for the federation, and being antipathy to the PRB leadership (Majid, 2007; Ahmad, 1989).

Malayan Prime Minister, Tunku Abdul Rahman was one of the supporter of Malaysia formation. In 1961 in a press conference in Singapore he stated that this territorial acquisition is very important for future Malays, politically also economically (Andaya \& Andaya, 2017). Lee Kuan Yew, Singapore Premier also showed his interest to join Malaya as pragmatic reason for Singapore dependencies in goods supply and trade access (Bintang Timur, 19 December 1962; Bintang Timur, 10 December 1962). At this early stage, despite strong opposition from Azahari and PRB, Indonesia through Foreign Minister Subandrio responded with statement of no objection, even support it as a good will from British to end colonialism. He wrote a letter to the New York Times in 17 November 1961, the act of sincerity and un-expansionist intentions to

"...let a quarter of Borneo Island, consisting of three colonies of the British Empire, be targeted by the Malayan Government to be melted. Of course, the people who live in the colonies are ethnically and geographically very close to the people who live in the Indonesian territory. However, we do not object at all to this Malaya... Instead, we expect the best for the Government of Malaya if we can succeed with this plan" (Wardaya, 2011).

In this political dynamic, Brunei became the most important party who determine which plan will be succeed. Rich with natural sources especially oil, stable, and demographically robust, its preference for both Malaysia and North Borneo formation was British interest although they were not so concern about Brunei in their existing status. Moreover, there was almost no demand from the highest authority, the palace, to do so even constitutional enactment in 1959 was Sultan initiative himself (Ahmad, 1989; Majid, 2007). Azahari and PRB, the relative newcomer to Brunei politic was the only party who pushed for a self-govern and public democratisation.

\section{Brunei Politics: The Sultan, People, and Foreigners}

Brunei's politics between the 1950s and 1960s can be mapped into three political spectrums: The Sultan and its bureaucracy as the traditional authority; Azahari and his supporters as representatives of modern political discourse; and British administration as colonial rulers. In 1953, the political movements began to take place in small Brunei Town, although easily broken by the British (Ahmad, 1989).

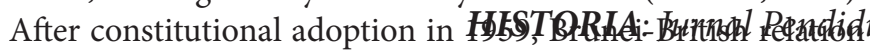

improved under a new agreement ended residency system and gave more autonomy for Bruneian, the Sultanate, to govern domestically. Foreign affairs along with security and defences matter remain under British responsibility. This new form of politics left PRB to lose some of their demand as democratisation and colonial residency issues (Bhattacharjee, 1976; Ahmad, 1989).

The formation of the PRB as central to the 1962 rebellion in 1956 stems from Azahari's visit to Singapore in 1955. There, he met many prominent Malay nationalist figures including the leaders of the Parti Rakyat Malaya (PRM) or Malayan People's Party such as Burhanuddin al-Helmy and Ahmad Boestamam. Azahari himself had contact with UMNO, but apparently, the revolutionary spirit he gained during his youth in Indonesia brought him ideologically closer to PRM rather than UMNO. In addition to fighting for Pan-Malayism idea, in its constitution, the PRB guarantees the Sultan's position within the form of constitutional monarchy. Good communication with the British was done even since the founding of the organization, which even gained the British Commissioner's sympathy for the aspiration of Bruneian. Aside from PRM, $\mathrm{PRB}$ also began to establish relationships with Indonesian figures and organizations such as Partindo, Gerwani, and GPI (Harry, 2015; Ahmad, 1989).

PRB relations with the British began to deteriorate when the aspirations of self-government in 1957 memorandum submitted to the colonial office in London, ignored. Sultan himself in proposed another constitution in 1957 during his visit to Britain. In 1958, the Sultan's reaction to the PRB proposal was made clear by the doubts and objections it showed. The Sultan requested that the people "be patient and do not rush" in the process towards independence. Along with the constitution enacted in 1959, the PRB retaliated by rejecting all forms of absolute monarchy still contained therein. The issue of citizenship for the Dayak tribe was also an aspect of objection as it allows for the citizen caste (Ahmad, 1989; Harry, 2015).

The worsening relationship with the Sultan also increased with Malaysia's proposed formation from Malayan Prime Minister, Tunku Abdul Rahman. This proposal was first responded by the Sultan in December 1961 during a royal court meeting with a good and positive welcome (Ahmad, 1989). PRB themselves was long before the Tunku statement had rejected the possibility of merging all British colonial territories in Southeast Asia. Leftist-socialist parties did the same on the peninsula and Singapore. PRB and the Sultan were not present at the first meeting of Malaya, Singapore and North Borneo delegations in Kinabalu, Sabah, August 1961, although Brunei sent an observer delegation to the second session in Kuching, Serawak four months later. The PRB itself had a desire to present its aspirations in the talks but was not involved because of the "anti-PRB in the palace" attitude. Many Sultans' advisors convinced him that the PRB was antimonarchy (Harry, 2015; Jamil, 2003).

According to Zaini, Sultan's advisory groups that can be categorized as local aristocrats, officers assisted from Malaya, and pro-British faction has made the Sultan's stance fickle (Ahmad, 1989). If previously he rejected the merger policy,

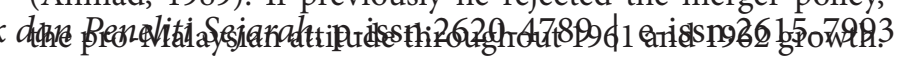


The Sultan's 1961 stance aroused suspicion with the suggestion of forming Brunei Royal Force as a "state" military, an interest that even the British questioned its effectiveness (Manan, 2015; Majid, 2007). British administrator even put concern over Sultan capability on political decision, as D. C. White, the High Commissioner in Brunei write. He was in doubt about Sultan understanding in democracy while Selkirk further mentioned his concern for Sultan "mental instability", a "polite" words for fickle attitude (Majid, 2007).

Through victory in the 1962 general election, PRB requested the opening of parliament to hold a national constitutional plebiscite. However, the scheduled session in October was delayed until 5 and 6 December 1962. The schedule was later postponed again by the Sultan for the mid-December without any reasonable basis. British officer warned of a public reaction to the delay, but another fear that PRB through parliament would gain greater sympathy and ultimately erode the royal's power, caused the warning to be ignored (Harry, 2015).

\section{Rebellion and International Responses}

Seeing the Sultan's closed and arrogant attitude with parliamentary delays, while the temporary National Assembly - filled with most monarch supporters - in its meeting in August passed Brunei's unification with Malaysia. PRB reacted by holding meetings at Azahari residence, Kampung Padang, Brunei in early December 1962. The TNKU formed in August 1961 to prepare the worst possibilities in case British become repressive as they did to the Parti Kebangsaan Melayu Malaya (PKMM) or Malayan National Party in 1948 in the Peninsula. Indonesia assisted the training of TNKU officers from early 1962 conducted in the Indonesian Borneo. However, Indonesia's involvement itself only came after the confrontation politics was announced in 1963 (Pour, 1993; Ahmad, 1989).

The rebellion began at 2 AM, 8 December 1962 with the proclamation of independence in Bukit Sumur, Brunei Town, by Deputy Prime Minister, Jasin Affandi. At the same time, the proclamation also held in Manila by Prime Minister, A.M. Azahari (Ahmad, 1989; Bintang Timur, 10 December 1962). TNKU then launched an offensive at dawn by raiding police headquarters all over Brunei, including to the Sultan's Palace and the House of the Chief Minister. In the process, apparently, the information that was widespread in Limbang to the British Resident there warned of a mass movement on 19 December made the police readier. Indeed, the TNKU failed to capture the Sultan at the Palace due to poor coordination. The plan would be forcing the Sultan to announce proclamation in front of the newly built Grand Mosque in Brunei Town. The plan to capture Chief Minister also failed due to police reinforcement that outnumbered TNKU (Majid, 2007; Jamil, 2003; Shaw, 2016).

If the movement of TNKU in the capital failed, Seria oil town occupation was quite a success. Shell's airfield was occupied before the arrival of British aid troops. Meanwhile, in a hurry, Negara Kesatuan Kalimantan Utara (NKKU) or Union State of North Borneo officials have withdrawn to the interior. Some areas in Sarawak have been controlled by TNKU HISTORIA: Jurnal Pendidik dan Peneliti Sejarah, p-issn:2620 for a while but were not long. The situation in Brunei Town was gradually normal within hours. The Sultan and the Chief Minister were almost secure under police guard (Ahmad, 1989; Bintang Timur, 12 December 1962).

In the morning of 8 December, Sultan announced via radio on the illegal movement of TNKU which was then connected to the Chief Minister calling for the handover of weapons from all the people. The Sultan with information from the Minister and the police, contacted Lord Selkirk to help restore the situation with the support of British troops (Majid, 2007). Selkirk forwarded this information to the colonial official in Singapore who immediately ordered the deployment of troops from its base in Labuan. Around 10:30 am, TNKU mobilized hundreds of its members to march on the main road of Brunei Town, which immediately confronted by the newly-arrived troops. The clash broke out, gunfire was released, but the number and armament of the rebels were not much, and that afternoon they surrendered. Thousands of TNKU members fled to the Indonesian border, while many were arrested (Hadiningrat, 1971; Majid, 2007; Poulgrain, 2014). According to Zaini, about 2000 people have been detained in Berakas, Brunei, later that year (Ahmad, 1989; Bintang Timur, 27 December 1962).

Regarding the state declaration of emergency Sultan dissolved all political institutions from the national to local level, making him the only political authority in Brunei. The curfew was enforced, and an Emergency Assembly was established. The Chief Minister dissolved PRB on 10 December and provides a high reward for anyone who can provide information to capture the members of TNKU (Majid, 2007; Ahmad, 1989; Bintang Timur, 14 December 1962). British seems unwilling to compromise with the situation and brought more troops of Gurkha, tanks, warships, and panzer. Royal Air Forces were also deployed to Brunei from Singapore. The hunt for TNKU figures within the territory of Brunei continued at least until early 1963, including the killing of Brigadier Sheikh Othman - one of the prominent TNKU commanders - in Kampung Bunut, Brunei (Ahmad, 1989; Bintang Timur, 26 December 1962).

Along with logistic and police support, Malayan Prime Minister, Tunku Abdul Rahman unwisely made an open statement condemning the Indonesian government and accusing of being main actor in the Brunei Revolt on 11 December (Merdeka, 12 December 1962, Harian Rakjat, 13 December 1962, Bintang Timur, 12 December 1962). Despite of real support as ideological ties, Indonesia also respond in 15 December as President Soekarno stated openly that “... the Indonesian people are sympathetic to the people of North Borneo". This statement was reinforced by the decree of the Majelis Permusyawaratan Rakyat Sementara (MPRS) or Provisional People's Consultative Assembly, which mandated the state to support the North Borneo people struggle according to the principle of the Dasasila Bandung (Asian-African Conference Declaration) (Bintang Timur, 26 December 1962; Ahmad, 1989). Meanwhile, the provocative statements of the Tunku and the British which submitted to the media accused the involvement of Indonesia as the mastermind of the rebellion insurgency answered in January 1963 by Foreign Minister 620-4789 | e-issn:2615-7993 
Subandrio who declared, "to answer the Tunku challenge" as a signal of further action from Indonesia (Bintang Timur, 17 December 1962; Wardaya, 2011).

Despite of Tunku personal preference to blame Indonesia for the Brunei Revolt, some of Malayan opposition parties supported PRB and Azahari. According to Zaini, 28 members of parliament from opposition Islamic Party, Progressive Party, and Socialist Front, left the chamber during Tunku speech about Brunei matter (Ahmad, 1989; Duta Masyarakat, 29 December 1962). Many of Asian-African nations show support at least diplomatically to NKKU as the forum of Asian-African Solidarity Conference raised the issues in February 1963 even declared to recognise it as a sovereign state. PRC also granted its limited recognitions in the conference (Bintang Timur, 15 December 1962). The only problems here was its lack of real action to support NKKU, besides Indonesia as the primary supporter.

The severe effects from this event continued to escalate and sparked further international demands for transparency in decolonisation process. Indonesia turned against the establishment of the federation and accused it as a British neo-colonialism product which opposed by the North Borneo people. Despite Indonesia's disappointing voices since mid1962 because of seemingly fraudulent Cobbold Commission report, a finding commission for people aspiration about Malaysian initiative, an open opposition began after the uprising (Majid, 2007). The Philippines raised the issue of Sabah as its territorial claim (Poling, DePadua, \& Frentasia, 2013; Bintang Timur, 17 December 1962). Britain and Malaysia turn to accuse Indonesia of being one of the rebellion provocateurs. The culmination of this situation was the continued hostilities of the following year known as Confrontation.

Confrontation was an open policy of hostility or opposition through various media: politics, economy, and even military officially run by Indonesia since March 1963 declared by Sukarno in Yogyakarta against Malaysia (Andaya \& Andaya, 2017). At least in 1963-1965 the closed military operation of Dwikora was conducted by Indonesian military forces and TNKU, with a guerrilla tactic in North Borneo. The British deployed regular troops in the unpublished war. It occurred for next two years effectively until the September 30th incident in Indonesia happened. The dissolution of Indonesian Communist Party and the regime change to Suharto ended this politics in 1966 and the normalization of relations between Indonesia and Malaysia was done through the Bangkok 1967 meeting as well as the founding of ASEAN (Sekneg, 1978; Wardaya, 2011).

\section{CONCLUSION}

Apart from the PRB movement as a political group actively seeking support both at home and abroad, the rebellion that occurred at the end of 1962 was an effect of traditional leadership that was nervous about the situation. The Sultan as the highest figure in the existing political structure - and until that time still had a powerful position - became a crucial determinant in the political decisions that must be taken. When a careful and too dilatory attitude was inclined to be fickle and unresponsive, then the reaction appears to be very destructive. We can see that the Sultan's stern stance was desirable, not only by the PRB and its supporters but also by the British regarding the decolonization proposals.

If we further link the perspective of the Sultan's responsibility in the $\mathrm{PRB}$ rebellion with existing views about Indonesia, the British and Shell Oil Company, as well as interPRB itself, then the three were the victim of the situation. Indonesia with its political position in a race for a global influence, plus ideological closeness with Azahari in particular, has no choice but to support PRB movements facing an uncooperative and reluctance Sultan. Britain and Shell who obviously have economic and political interests in the region were likely to be provoked to "convince" the Sultan of the potential magnitude of chaos if only he did not immediately take a clear position on the future of his country. The internal side of the PRB itself, with its clear people mandate, has a strong reason to show power in front of the ruler arrogance that seized the people's democratic right. The silence of the party from the reaction will greatly deteriorate the party's image as a "talks group" who has no tactical strategy.

From a historical view, the Brunei rebellion becomes an interesting object to show how the historicity of the event is not only determined by size, duration, or eventuality but also the effects that follow. Although it can be crushed in a short time, this event quickly escalates to involve many parties into other highly complex events. These effects besides political and military conflicts were also wars of discourse and perspective, becoming the narration of the past that occasionally arose in the sense of nationalism sentiment in the problems faced today. As for the historical interpretation itself, it seems that the historians' absence from criticism of Brunei's monarchy as expressed in this study is closely related to the regime's continued, respected, and sacred by its people. It became a barrier to the study to give a proportional side on its involvement. How is it possible to criticize this position? Does history need to be silent when situations are not possible?

\section{REFERENCES}

\section{Published Documents}

Ahmad, Haji Zaini bin Haji. (1989). Pertumbuhan Nasionalisme di Brunei (1939-1962) [Nationalism Development in Brunei (1939-1962)]. Kuala Lumpur: ZR Publications.

Sekretariat Negara RI. (1978). 30 Years of Indonesia's Independence 1966-1975. Jakarta: Sekretariat Negara RI.

\section{Newspapers}

Nurfauzi, "Brunei dan Malaysia bagian I, Sebab Inggris daratkan pasukanja dan tindak revolusi rakjat K.U. [Brunei and Malaysia Part I, British causes to send its forces and fighting North Borneo people revolution]", Bintang Timur, 15 December 1962, p. 3.

Nurfauzi, "Brunei dan Malaysia bagian IV, 'Malaysia': bukan djalan ke kemerdekaan [Brunei and Malaysia Part IV, 'Malaysia': not a way for independence]', Bintang Timur, 19 December 1962, p. 3.

"Pemberontakan Meletus di Brunei [Rebellion broke out in Brunei]", Bintang Timur, 10 December 1962, p. 1. 
"Pemberontakan di Brunei [Rebellion in Brunei]", Bintang Timur, 10 December 1962, p. 2.

"Soal Brunei [Brunei Issue]", Duta Masyarakat, 11 December 1962 , p. 2.

"Pemberontakan yang Benar [The rightful Rebellion]", Bintang Timur, 11 December 1962, p. 2.

"Rakjat Brunei minta sokongan Bung Karno [Bruneian ask Sukarno Support]", Bintang Timur, 12 December 1962, p. 1.

“Tengku mendakwa dan bawa-bawa nama Indonesia [Tengku accused Indonesia]", Bintang Timur, 12 December 1962, p. 1.

“Tengku Kirim Polisi [Tengku sent Police]”, Merdeka, 12 December 1962, p. 2.

"Tengku memfitnah dan mengkambinghitamkan Indonesia [Tengku slandering and scapegoating Indonesia]", Harian Rakyat, 13 December 1962, p. 1.

"Kawat Azahari kepada negara-negara Asia-Afrika: Indonesia diminta kirim sukarelawan [Azahari calls to AsianAfrican nations: asked Indonesia to send militia]", Bintang Timur, 14 December 1962, p. 1.

"KSRAA dukung rakjat K.U. [KSRAA support North Borneo people]", Bintang Timur, 15 December 1962, p. 1.

"Pernjataan offensive dan menghina harus diakhiri, Indonesia akan terima tantangan bila PM Malaya terus bersikap tegang [Offensive and insulting statements must be ended, Indonesia will accept the challenge if Malayan PM continues to be hostile]", Bintang Timur, 17 December 1962, p. 1.

“30.000 sukarelawan Filipina ditawarkan kepada Azahari [30.000 Philippine militia offered to Azahari]", Bintang Timur, 17 December 1962, p. 1.

"Pengkhianatan terhadap Dasa-Sila Bandung [Betraying against Dasa-Sila Bandung]", Bintang Timur, 26 December 1962, p. 1.

"RI tidak claim daerah lain [Indonesia does not have territorial claim]", Bintang Timur, 26 December 1962, p. 1.

“Kedok Tengku dibuka Harian 'Manila Chronicle', Pelaez Marah-marah dan Bantah Tuduhan Tengku [Tengku Intentions revealed by 'Manila Chronicle', Pelaez angry and denied Tengku allegations]", Duta Masyarakat, 28 December 1962, p. 2.

"Apa kata pemuda Malaja? PM Tengku Budak/ Agen Imperialis di mata rakjat Asia-Africa [What Malaja youth say? PM Tengku is Imperialist agent]", Duta Masyarakat, 29 December 1962, p. 2.

\section{Books}

Adam, Ramlah. (2004). Kemelut Politik Semenanjung Tanah Melayu (Malay Peninsular Political Turmoil). Kuala Lumpur: Publisher Universiti Malaya.

Andaya, Barbara Watson \& Leonard D. Andaya (2017). A History of Malaysia third edition. London: Palgrave.

Bakar, Nani Suryani Abu. (2014). "Brunei and the British Decolonization Policy, 1950-1966”. Susurgalur: Journal of History \& History History, 2 (2), September, pp. 123-140.

Bhattacharjee, G.P. (1976). Southeast Asian Politics: Malaysia \& Indonesia. Calcutta: Minerva Association.

HISTORIA: Jurnal Pendidik dan Peneliti Sejarah, p-issn:2620-4789 | e-issn:2615-7993
Deery, Philip, (2007). "Malaya, 1948 Britain's Asian Cold War?”. Journal of Cold War Studies, 9 (1), Winter, pp. 2954.

Hadiningrat, K. (1971). Sedjarah Operasi2 Gabungan dalam Rangka Dwikora, Seri Text-book Sedjarah ABRI. Jakarta: Dephan RI.

Harclerode, Peter. (2001). Fighting Dirty. The inside story of covert operations from Ho Chi Minh to Osama bin Laden. London: Cassell \& Co.

Harry, Kathleen. (2015). The Brunei Rebellion of 1962. PhD Thesis. Charles Darwin University, Darwin.

Herlina, Nina. (2011). Metode Sejarah. Bandung: Satya Historika.

Jamil, Pehin Dato. (2003). 8 Disember: Dalanguya Siapa? [8 December: Who is the Culprit?]. Bandar Seri Begawan: Pusat Sejarah Brunei Kementrian Kebudayaan, Belia dan Sukan.

Kahin, George McTurnan. (2001). Southeast Asia, A Testament, London: Routledge Curzon/

Kuntowijoyo. (2005). Pengantar Ilmu Sejarah. Yogyakarta: Penerbit Bentang.

Langlois, Ch.V. \& Ch. Seignobos. (2015). Introduction to the Study of History. Yogyakarta: Indoliterasi.

Majid, Harun Abdul. (2007). Rebellion in Brunei: The 1962 Revolt, Imperialism, Confrontation and Oil. London-New York: I.B. Taurus.

Manan, Wafi Abdul. (2015). Brunei's Preference for British Protection: Ontological Insecurity After the 1962 Rebellion. MA Thesis. Georgetown University, Washington D.C.

Poling, Gregory, Phoebe DePadua and Jennifer Frentasia. (2013). "The Royal Army of Sulu Invades Malaysia”. CSIS Critical Questions, published 8 March, accessed 30 October $2017<$ https://www.csis.org/analysis/royal-army-suluinvades-malaysia $>$.

Poulgrain, Greg. (2014). The Genesis of Confrontation Malaysia, Brunei, and Indonesia 1945-1965. Petaling Jaya: Strategic Information and Research Centre.

Pour, Julius. (1993). Benny Moerdani Profil Prajurit Negarawan [Benny Moerdani A Profile of Statesman Soldier]. Jakarta: Yayasan Kejuangan Panglima Besar Soedirman.

Shaw, Alexander Nicholas. (2016). "British counterinsurgency in Brunei and Sarawak, 1962-1963: developing best practices in the shadow of Malaya". Small Wars \& Insurgencies, 27 (4), pp. 702-725.

Tarling, Nicholas. (1993). The Fall of Imperial Britain in South-East Asia. Singapore-Oxford-New York: Oxford University Press.

Wallerstein, Immanuel. (2010). "What cold war in asia? An interpretative essay ", in Zheng Yangwen, Hong Liu Michael Szonyi (eds.), The Cold War in Asia The Battle for Hearts and Minds. London-Boston: Brill Publisher, pp. 15-24.

Wardaya, Baskara T. (2011). Indonesia Melawan Amerika Konflik Perang Dingin 1953 - 1963 (Indonesia vs America Cold War Conflict 1953-1963). Jakarta: Galang Press Printing. 